\author{
ANNALS OF THE \\ UNIVERSITY OF CRAIOVA
}

Series: $\checkmark$ Biology

$\checkmark$ Horticulture

$\checkmark$ Food products processing technology

$\checkmark$ Environmental engineering

\title{
Vol. XXVI (LXII) - 2021 \\ PRELIMINARY RESULTS REGARDING THE BEHAVIOUR OF DIFFERENT APRICOT VARIETIES UNDER DIFFERENT PLANTING DENSITY
}

\author{
Moloșag Ailin ${ }^{1 *}$, Dumitru Maria1 , Căliniță Cristian ${ }^{1}$, Drăgan Gherghina1, \\ Dragnea Maria $^{1}$, Dogaru Mihaela ${ }^{1}$, Dragomir Damian ${ }^{1}$, Petrișor Cristina ${ }^{2}$ \\ ${ }^{1}$ Fruit Research and Development Station Băneasa Bucharest \\ ${ }^{2}$ Research Development Institute for Plant Protection Bucharest \\ *Correspondence author. E-mail: molosag.ailin@scdpbaneasa.ro
}

Keywords: apricot, varieties, planting densities, growth dynamic

\begin{abstract}
Apricot cultivation and breeding have a long history in Romania. To keep up and maintain this tradition, continuous research is needed in order to identify the varieties and rootstocks that are able to generate high yields that are suitable for crop intensification and are aiming to reach the international standards, cultural trends and the actual economic context. During our study we have found that the planting distance influenced especially the average shoot length increase (ASLI - $\mathrm{mm}$ ). The average trunk diameter increase (ATDI - $\mathrm{mm}$ ) and average shoot length increase (ASLI - $\mathrm{mm}$ ) are linked together and varied according to the genotype studied. Also, a correlation was found between ATDI - $\mathrm{mm}$ and ASLI - $\mathrm{mm}$, described by the equation $\boldsymbol{y}=\mathbf{0 . 8 0 1 9 x}$. The related coefficients $\boldsymbol{R}^{\mathbf{2}}=\mathbf{0 . 8 9 3 8 ^ { * * * }}$ and $r=0.9455^{* * *}$, are statistically insured with a probability of $99.99 \%$.
\end{abstract}

\section{INTRODUCTION}

Apricot (Prunus armeniaca L.) is one of the oldest fruit species cultivated in mankind. For thousands of years, in different nations, these fruits have served not only as food but also as medicine (Miller et al., 1994; Chira, 1995). The spreading area of the cultivated apricot extends between the parallel $50^{\circ}$ Northern latitude and $35^{\circ}$ Southern latitude. Under certain conditions and localities with a favourable climate it can be cultivated further of the North (Gautier, 1988; Chira 1995). Apricot is an important fruit crop for the Southern and Western regions of Romania with a long tradition of cultivation (Bălan et al., 2008; Stănică et al., 2020).

During the past 30 years, orchard planting systems and tree canopies changed to the high and very high density planting. The different planting system have been successfully demonstrated in different fruit crops: peach and nectarine (Lal et al., 2018), apricot (Guerriero \& Scalabrelli, 1989; Kumar et al., 2013), apple (Comănescu et al., 2012), pear (Machado et al., 2014), cherry (Stănică and Eremia, 2014). The availability of low or medium vigour rootstocks for the most fruit species offer the possibility to increase planting densities in apple and pear, to more than 4,000 trees per hectare and in stone fruits, to over 2,000 trees per hectare (Stănică, 2019). 
Reducing planting distances is one of the strategies to increase yield in fruit (Auzmendi I. and Hanan, 2020). The main reason for its low productivity is non availability of high yielding varieties and lack of appropriate production technology especially planting density suiting to different climatic zones and region (Kumar et al., 2013) but high density orchards have been reported to have precocious and higher yield (De Jong et al., 1999; Lal et al., 2018).

The growth of shoots is a basic element to be considered in the relationship within growth and fructification, on which depends the fruit trees equilibrium respectively the production provision for year and next years (Enache et al., 2018).

The aim of this study was to determine the effect of planting density on properties of some apricot cultivars.

\section{MATERIAL AND METHODS}

The study was carried out at the Research and Development Station for Fruit Growing (RDSFG) Băneasa, Bucharest inside of the Experimental Base Moara Domnească, located N-E of Bucharest in Afumați, llfov County, in the Vlasiei Plain, a subunit of the Roman Plain. The site is located at $44^{\circ} 50^{\prime}$ Northern latitude and $26^{\circ} 24^{\prime}$ Eastern longitude and $70 \mathrm{~m}$ above the sea level. Continental temperate climate regime is specific for the area, with hot summers, frequent droughts and cold winters. The annual mean temperature is $12{ }^{\circ} \mathrm{C}$ and the total annual amount of precipitation is ranging between 550 and $600 \mathrm{~mm}$, the maximum occurring between May and July, torrential rains being common. The dominant air circulation direction is from the East and North-East in winter and from the West in the rest of the year, with a maximum wind speed of $12.6-14.4 \mathrm{~km} / \mathrm{h}$. The zonal soil type is reddish luvisol. In the depressed areas and in the crevices there are reddish luvisols and stagnosols.

In 2019, four apricot varieties ('Amiral', 'Elmar', 'Goldrich', 'Olimp') with different ripening periods: were planted. All apricot varieties were grafted on rootstock: Constața 14 (C 14). The canopy that was considered adequate for testing is: Bi-Baum $\circledast$. The apricot trees were planted at $4.0 \times 1.5 \mathrm{~m}\left(1.666\right.$ trees $\left.^{-1} \mathrm{ha}^{-1}\right), 4.0 \times$ $2.0\left(1.250\right.$ trees ha- $\left.^{-1}\right) \mathrm{m}$ and $4.0 \times 2,5 \mathrm{~m}\left(1000\right.$ trees ha- $\left.^{-1}\right)$, upon a randomized block design. The irrigation system is provided by drip pipes, with a flow rate of $1.6 \mathrm{l} / \mathrm{hour}$ $1.75 \mathrm{l} / \mathrm{hour}$. Between the rows, the soil was kept tilled and without grass.

Our experience is a bifactorial one and is carried out in order to observe the agrobiological potential of the varieties studied, aiming to intensify the cultivation technologies, through high density.

The chosen rootstock is Constanța 14 (C 14), a generative Romanian rootstock for apricots, obtained by selection in 1979 by Indreiaş Alexandra, approved in 1997. It has good affinity for grafting with all varieties in the assortment, induces high vigour, fruiting precocity and good fruit productivity and quality of grafted varieties.

In order to identify the most suitable variety and planting distance with the final goal of crop intensification, corroborated with the degree of maximization of the tree density, determinations were made on early stage growth of tree. The determination of observed characteristics was made in 2020 and 2021, at the end of the growth cycle, with electronic calliper and roulette for shoot length. Several tree growth indicators were analysed: the average trunk diameter increase (ATDI, mm), the average shoot length increase (ASLI, $\mathrm{mm}$ ) and the trunk cross-sectional area of tree $\left(\right.$ TCSA, $\left.\mathrm{cm}^{2}\right)$ was calculated by using formula TCSA $=$ Girth $2 / 4 \pi$ (Westwood et al., 1963). 
The collected data were processed with the facilities of MSExcel 2010 and are presented as tables and charts. The tables include statistical indicators as average, standard deviation and variation coefficients.

\section{RESULTS AND DISCUSSIONS}

A closer look in Table 1 reveals the influence of planting distance on the three synthetic growth indicators: the average trunk diameter increase (ATDI, mm), the average shoot length increase (ASLI, $\mathrm{mm}$ ) and the trunk cross-sectional area of the tree $\left(\mathrm{TCSA}, \mathrm{cm}^{2}\right)$.

When the apricot was planted at $1.5 \mathrm{~m}$ apart in the trees line, the ATDI - $\mathrm{mm}$ was $9.37 \mathrm{~mm}$ per season (STDEV=1.5445; VAR=16.4919), with the lowest increase $7.50 \mathrm{~mm}$ on 'Elmar' variety and the higher increase $11.27 \mathrm{~mm}$ on 'Goldrich'. Under similar conditions, ASLI - $\mathrm{mm}$ was $63.64 \mathrm{~mm}$ per season (STDEV=10.3350; VAR=16.2398), with the lowest increase $50.00 \mathrm{~mm}$ on 'Amiral' variety and the higher increase $75.00 \mathrm{~mm}$ on 'Goldrich' and TCSA - $\mathrm{cm}^{2}$ was 31.52 per season (STDEV=5.6238; VAR=17.8403), with the lowest increase $23.06 \mathrm{~cm}^{2}$ on 'Elmar' variety and the higher increase $37.36 \mathrm{~cm}^{2}$ on 'Goldrich'.

When the apricot was planted at $2.0 \mathrm{~m}$ apart in the trees line, the ATDI - $\mathrm{mm}$ was $10.74 \mathrm{~mm}$ per season (STDEV=1.5290; VAR=14.2329), with the lowest increase $8.66 \mathrm{~mm}$ on 'Goldrich' and the higher increase $12.33 \mathrm{~mm}$ on 'Olimp' variety. Under similar conditions, ASLI - $\mathrm{mm}$ was $83.28 \mathrm{~mm}$ per season (STDEV=5.2839; $\mathrm{VAR}=6.3446$ ), with the lowest increase $79.28 \mathrm{~mm}$ on 'Olimp' variety and the higher increase $90.55 \mathrm{~mm}$ on 'Elmar' variety and TCSA - $\mathrm{cm}^{2}$ was 34.96 per season (STDEV=6.9459; VAR=19.8703), with the lowest increase $25.82 \mathrm{~cm}^{2}$ on 'Goldrich' variety and the higher increase $40.43 \mathrm{~cm}^{2}$ on 'Olimp'.

Finally, when the apricot was planted at $2.5 \mathrm{~m}$ apart in the trees line the ATDI - $\mathrm{mm}$ was $9.60 \mathrm{~mm}$ per season (STDEV=1.5464; VAR=16.1123), with the lowest increase $7.99 \mathrm{~mm}$ on 'Olimp' variety, and the higher increase $11.48 \mathrm{~mm}$ on 'Amiral'. Under similar conditions, ASLI - $\mathrm{mm}$ was $88.97 \mathrm{~mm}$ per season (STDEV =9.2034; $\mathrm{VAR}=10.3441$ ), with the lowest increase $79.76 \mathrm{~mm}$ on 'Olimp' variety and the higher increase $101.21 \mathrm{~mm}$ on 'Amiral' variety and TCSA - $\mathrm{cm}^{2}$ was 30.54 per season (STDEV=6.0945; VAR=19.9527), with the lowest increase $24.81 \mathrm{~cm}^{2}$ on 'Goldrich' variety and the higher increase $38.57 \mathrm{~cm}^{2}$ on Amiral'.

Based on the accumulated data a linear correlation between average trunk diameter increase (ATDI, $\mathrm{mm}$ ) and average shoot length increase (ASLI, $\mathrm{mm}$ ) was calculated (Fig. 1). This correlation is described by the equation $\mathbf{y}=\mathbf{0 . 8 0 1 9 x}$, and even for $n=12-2=10$ pairs of numbers, the correlation coefficients $\mathbf{R}^{\mathbf{2}} \mathbf{= 0 . 8 9 3 8}$ and $r=\operatorname{sqrt}(0.8938)=\mathbf{0 . 9 4 5 5}$, are statistically insured, with a probability of $99.99 \%$.

Also, a positive correlation between Annual Cross Trunk Section Area Increase $\left[\mathrm{cm}^{2}\right]$ and Annual Shoot Length Increase [cm], described by the equation $Y=0.0275 x+6.9724$ with the coefficients $R^{2}=0.0144 ; r=\operatorname{sqrt}(0.0144)=0.1200 ; n=12-2$, but the coefficients are not statistically insured. 
$\sin$

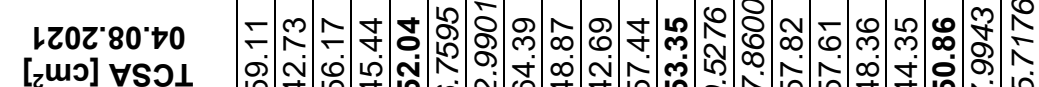

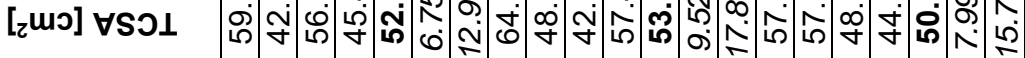

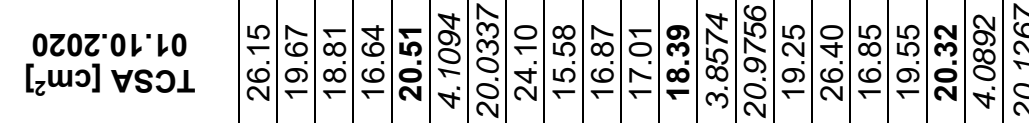

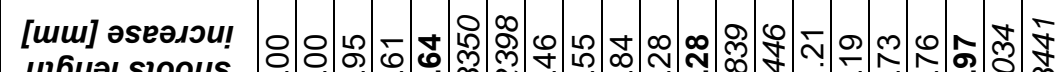
प76uә s7004s әбелән
IZ0Z'80't0 [wu] पұ6uә słoous
舟 ᄂ әбелә^
$\infty$ ப
人 ค.

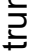

它 0Z0Z:0レ:L [um]

पұ6uә słoous әбеләл

令 空

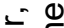

[шس] әsеәлои!

ләјәше!p

$\Phi$

чипл әбеләл

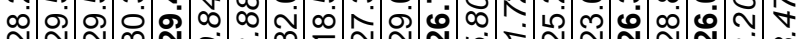
NNN N N 0 N

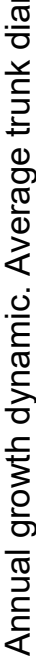

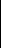

lZ0Z' $80^{\circ} t 0$

[uس] גәңәше!p

yund? әбеләл甘

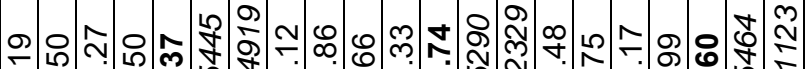
の)

(a)

0Z0Z'0レ'L [uس] dәғәше!p

J -

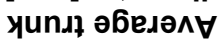

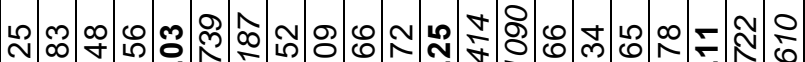

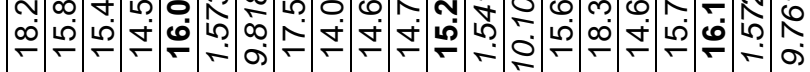

\begin{tabular}{|c|c|c|c|c|c|c|c|c|c|c|c|c|c|c|}
\hline 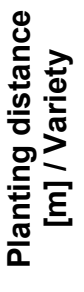 & 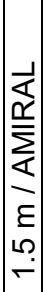 & 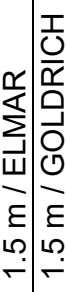 & 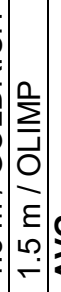 & 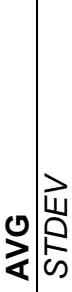 & 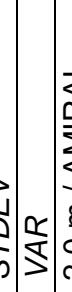 & 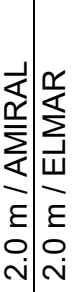 & 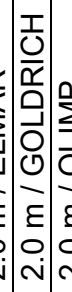 & 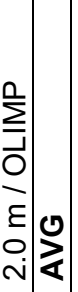 & 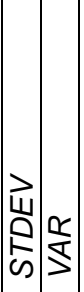 & 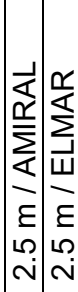 & 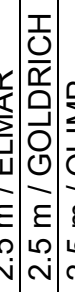 & 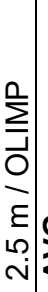 & 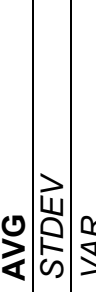 & \\
\hline 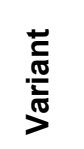 & & 5 & & $\begin{array}{l}\frac{\omega}{0} \\
\frac{0}{\mathbb{0}} \\
\frac{.0}{0} \\
\text { 드 }\end{array}$ & 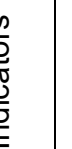 & & $\stackrel{\aleph}{\lessgtr}$ & & 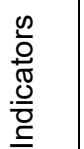 & & $\stackrel{m}{>}$ & & 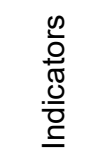 & \\
\hline
\end{tabular}




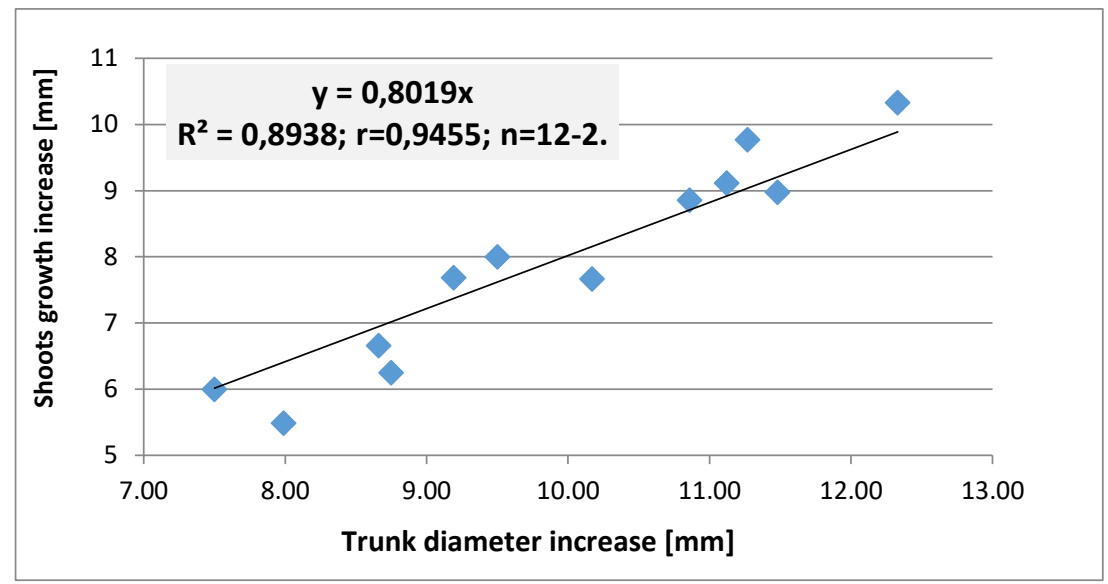

Figure 1. Correlation between average annual trunk diameter and average shoot length increase

\section{CONCLUSIONS}

The four varieties, grown by the Research and Development Station for Fruit Growing (RDSFG) Băneasa, Bucharest, under specific pedo-climatic conditions at Moara Domnească Experimental Base are adapting and performing well in the juvenile phase.

Based on the presented data we found that the planting distance influenced both, average trunk diameter increase (ATDI, mm) and average shoot length increase (ASLI, $\mathrm{mm}$ ) of all four studied apricot varieties. In the juvenile phase of the apricots, the average trunk diameter increase (ATDI - $\mathrm{mm}$ ) and average shoot length increase (ASLI - $\mathrm{mm}$ ) are linked together and varied according to the genotype studied as well as have valorised the chosen rootstock C14 and the applied technological measures as well.

Regarding the synthetic growth indicator TCSA $-\mathrm{cm}^{2}$ the highest value for: $(4 \times 1.5 \mathrm{~m})$ planting distance is recorded by 'Goldrich' with $37.36 \mathrm{~cm}^{2},(4 \times 2 \mathrm{~m})$ planting distance is recorded by 'Olimp' with $40.43 \mathrm{~cm}^{2}$ and $(4 \times 2.5 \mathrm{~m})$ planting distance is recorded by 'Amiral' with $38.57 \mathrm{~cm}^{2}$. This indicator is of great importance for future studies, because by using it is possible to correlate the productivity of selected varieties with the planting distances in super-intensive cropping system.

\section{ACKNOWLEDGMENT}

This paper was elaborated inside ADER 711 Project 'Researches on the agrobiological potential of some varieties and rootstocks of thermophilic species of fruit trees and shrubs in order to intensify cultivation technologies', funded by the Agriculture and Rural Development Ministry.

\section{REFERENCES}

Auzmendi I., Hanan J., 2020. Investigating the effects of planting density and tree size on yield through functional-structural modeling. Acta Hortic. 1281, 523-532. Doi: 10.17660/ActaHortic.2020.1281.69. 
Bălan V., Topor E., Tudor V., Stănică F., Hoza D., Chira A., Chira L., Marin I., Nistor E., Asănică A., 2008. Caisul şi caisele (Apricot and apricot fruits). Edit. Ceres, Bucureşti, ISBN 978-973-40-0797-4, pg. 686.

Chira A. 1995. Influența unor măsuri agrotehnice și tratamente post-recoltare asupra calității și comportării în procesul valorificării a fructelor de cais. Teză de doctorat, USAMV București, Facultatea de Horticultură, București, pp. 1.

Comănescu D., Petre G., Petre Valeria, 2012. The behaviour of some apple tree varieties with genetic disease-resistance in the high density system. Scientific Papers. Series B, Horticulture, Vol. LVI, ISSN Online 2286-1580, Print ISSN 22855653, 63-68.

DeJong T. M., Tsuji W., Doyle J. F., Grossman Y. L., 1999. Comparative economic efficiency of four peach production in California. Hort. Sci. 1999; 34:73-78.

Enache V., Croitoru M., Dima M., 2018. Research on the variety influence on vegetable growth at apricot species in sandy soils conditions in southern Oltenia. Scientific Papers. Series B, Horticulture, Vol. LXII, Print ISSN 2286-1580, 25-28.

Gautier M. 1988. La culture fruitiere. Les productions fruitieres, Vol. 2, p. 292 - 337.

Guerriero R., Scalabrelli G., 1989. Six years observations on apricot high density plantings. Acta Hort. 243, Orchard and Plantation Systems, p. 365-369.

Kumar D., Ahmed N., Verma M. K., Dar T. A., 2013. Growth, yield, quality and leaf nutrient status as influenced by planting densities and varieties of apricot. Indian J. Hort. 70(2), June 2013: 00-00, p. 126-130.

Lal S., Sharma O.C., Singh D. B., Rather S. A., Qureshi I., 2018. Tree growth, fruit quality and yield attributes as affected by tree spacing and varieties of peaches/nectarine under temperate climate. International Journal of Chemical Studies 6(2): 308-311, p. 308-311.

Machado B. D., Rufato L., Kretzschmar A. A., Bogo A., Silveira F. N., Magro M., 2014. Effect of plant densities and cultivars on vegetative and productive variables of European pears in Southern Brazil. Proc. $X^{\text {th }}$ IS on Integrating Canopy, Rootstock and Environmental Physiology in Orchard Systems, Ed. K. Theron, Acta Hort. 1058, ISHS 2014, p. 193-197.

Miller D., Vannier P. 1994. Le grand livre des fruits et legumes. Histoire, culture et usage. Ctifl, Paris, p. 266 - 267.

Stănică F. 2019. New tendencies in fruit trees training and orchard planting systems. Scientific Papers. Series B, Horticulture, Vol. LXIII, Issue 2, Print ISSN 2285-5653, 25-34.

Stănică F., Butcaru A.C., Mihai C. A., Florea I. M. and Șerban D. 2020. Preliminary results regarding the behaviour of some new apricot cultivars in București area. RJH Vol. I, 2020: 59-66, DOI: 10.51258/RJH.2020.08.

Stănică F., Eremia A. 2014. Behaviour of some new apricot cultivars under the parallel trident planting system. 10th ISHS International Symposium on Orchard Systems, Stellenbosch Univ. (3-6 Dec.) Acta Hort. (ISHS) 1058:129-136.

Westwood M. N., Reimer F. C., Quackenbush V. L., 1963. Long term yield as related to ultimate tree size of three pears varieties grown on rootstocks of five Pyrus species. Proc. American Soc. Hort. Sci. 1963; 82:103-8. 